\title{
Ministerial Leadership: The Servant Leader as a Transformational Leader
}

\author{
Remi Alapo \\ Unification Theological Seminary
}

\begin{abstract}
This paper provides a different meaning on the role of the Pastor or Ministry Leader as a "servant leader" referencing the text—“Pastor: The Theology and Practice of Ordained Ministry” by William H. Willimon (2002), ${ }^{1}$ where the author describes the ordained ministry as "a is a gift of God to the church" which usually does not mean that it is an easy task but rather, more complex and challenging as ministry leaders or pastors feel a call to transforming societies beyond their calling. In post-modern society, the pastors' role has differed and extended to form in line with creating a just and beloved community. In such communities, the pastor has more interaction with the community and the day to day activities of its neighbors or hosts. The purpose of this paper is to understand leadership and the role of the Ministry leader as a transformational leader, that goes beyond the role of being a servant leader.
\end{abstract}

Keywords: transformational leadership, ministerial leadership, church leadership, organizational leadership, servant leadership

\section{Introduction}

An exploration into some of the central questions about the exact vocation of "ordained ministry" begins with a discussion of who pastors are, and how the theological underpinnings of ordained ministry moves to what pastors do, and the distinctive roles that pastors as servant leaders, must fulfill as part of their calling. While Christian ministry has changed, in respect of its core concerns such as preaching the word and caring for souls in the beloved community, the sacramental life of congregations has remained the same.

Many Pastors or Ministry Leader in ministry believe that they have power to lead people which is true but different powers exist that can either make a pastor to be a "Celebrity minister" or break a church apart like we have seen in many mainstream churches as well as local or community ones. "Ordained ministry is a vocation to which we are called, not a profession that we choose. To answer that call is to open oneself to heartache and sometimes hardship; yet, given the one who calls, it is to make oneself available to deep and profound joy as well.” Discussing Niebuhr's criteria, Willimon describes the peculiarity of Christian leadership and describing the Acts of Apostles as the basis of Christian Leadership. He discussed that the book of Acts narrates the triumphs, tribulations of leaders. The story of a man named Ananias is of interest, because he was a man who sold property (with the consent of his wife Sapphira), brought back only some of the proceeds to be laid at the feet of the Lord.

Remi Alapo, Doctor of Management (D.M.), Organizational Management and Leadership, University of Phoenix, Arizona, DMin. (Doctor of Ministry Program), Unification Theological Seminary, USA; main research field: Peace and Justice Administration. 
Ananias was rebuked by Peter for his acts asking “Ananias, why has Satan filled your heart to lie to the Holy Spirit and to keep part of the proceeds of the land? While it remained unsold, did it not remain your own? And after it was sold, were not the proceeds at your disposal? How is it that you have contrived this deed in your heart? You did not lie to us but to God!” Willimon further went on to describe the story of Ananias according to the book of Acts 5:15 that when Ananias heard these words from Peter, he fell and died! Afterwards, everyone who heard of this story was seized by fear!

\section{The Pastor or Ministry Leader as a Person in Position of Power}

This story serves as a good reminder of leaders in early biblical leadership. For example, according to the book of Acts 5:3, Peter did not accuse Ananias of greed but of lying to the Holy Spirit. Lying to the Holy Spirit is the same as lying to God according to the Act 5:4. Willimon posited that the Christian community is close to God and that lying to the Church is the same as lying to God-hence, ineffective leadership and a poorly led ministry. The pastor as a person in position of power does not mean abuse of authority. The ability of an ordained pastor or lay ministry leader to possess power goes beyond spiritual anointed power.

Power is one person's ability to exert change on another person's way of life and actions. Using power is a valuable means to influence and achieve intended desires and future action in others. Power is instrumental; it's a means to achieve goals other than the attainment of power itself. Power may also be expressed as one person's dependence on another. Power can, and sometimes is, a goal; its basic use is instrumental in the achievement of one's goals or aims. (Alapo 2018, 1) ${ }^{2}$

\subsection{The Minister as a Leader}

"Leadership is the process whereby one individual influences other group members toward the attainment of defined group or organizational goals...”3 In many churches, many ordained or lay ministers are not equipped with good leadership or managerial skills. Beyond the call of preaching the gospel and stewardship, they rarely know anything about being in leadership positions or how to work with people in their ministries or in their host communities. Many have been exposed for embezzling of funds, misappropriating church donations and funds, mismanagement of property, and conducting other illicit activities that do not speak well to congregations or faith communities. The key to successful management of churches and members is understanding leadership because "leadership philosophy is conceptualized as the leader's values, behavior, and attitudes." ${ }^{4}$ Leadership is of managing people, churches, and communities so that members of churches and those in the community can look up to the pastor or minister as a leader. ${ }^{5}$

In ministerial leadership, there are different roles of the Pastor or Ministry Leader. One such role is the Pastor as a transformational leader. Most of the pastor's time is given to congregational leadership incorporating teachings of the living presence of Christ and advent of the kingdom of God. Most pastors have a good purpose of the calling into ministry and why they would like to serve God. Many pastors also understand that they need to preach the gospel of Christ and win souls for Christ by motivating their congregation with the teachings of Christ. Pastors according to Willimon are ordained by the church to lead a "community of persons" ${ }^{\prime 6}$ whose lives are dependent on their community or religious beliefs.

With the leadership of Pastors or Ministers as transformational leaders, congregants or communities where churches are based can be motivated to share in the building of a Christian community leading each person closer to the kingdom of God-vision and goal setting. The pastor as a person in position of power has the authority as the overseer of a church or community—an administrator. This power is also limited by those who 
oversee the actions of the leader - Church or other boards. Understanding the pastor's role as a leader is also very useful to understand the pastor's purpose of why they are ordained. The most fruitful purpose besides motivating with the word of God is the role of the pastor to understand him or her as a transformational leader.

\subsection{The Pastor as a Transformational Leader ${ }^{7}$}

The transformational leadership style is the most sustainable type of leadership. Leaders engage this style of leadership not only because it gets the job done in the immediate, but also because it changes people's lives, effecting a lasting effect on relationships. It is important to mentor and inspire subordinates to deliver more effectively. ${ }^{8}$

The key concepts or theories in transformational leadership are creating a vision to model and transform others to become change agents in the societies. ${ }^{9}$ This change agent transformation is achieved through the generation of awareness and motivation that looks beyond those of the leader who will benefit the organization or followers. ${ }^{10}$ Transformational leaders according to Bass ${ }^{11}$ are very inspirational and charismatic. They lead by example, are encouraging, motivating, inspirational, and they mentor by showing personal examples. ${ }^{12}$ These leaders are often motivational and always offer intellectual stimulation by putting other people into consideration before their own needs. ${ }^{13}$ Transformational leadership theory has four dimensions: charisma, inspirational dimension, individual consideration, and intellectual stimulation. ${ }^{14}$ A qualified leader displays all four dimensions of transformational leadership theory, goes beyond the call of duty, sacrifices to serve constituents and achieve goals set by the group. In return, such a leader is respected. ${ }^{15}$

\section{Ten Innovative and Useful "Rules of Leadership" 16}

Willimon provided ten innovative and useful "rules of leadership”"17 which are applicable to pastors or ministry leaders serving in communities where people are resistant to change:

(1) The first rule is to "Give back responsibly:" Understanding and encouraging members and helping them to reclaim their calling and not discourage them. For example, a pastor as a transformational leader can encourage lay people or counsel them as someone that they look up to or share ideas with.

(2) The second rule is to "expect trouble:" because many pastors view themselves as authorities or leaders and hope to be liked when giving advice and opinion, pastors or Christian leaders need to have an open mind to deal with changes of their congregants. Giving example from the Gospel according to the book of Mark which typically relates to conflict, Willimon stated that "trouble comes with territory when the truth is involved.”

(3) The third is to "value small steps:" While it is good to have a long-term vision, getting there step-by-step thinking of the nature of the gospel valuing small thing will be appreciated by those we lead in our ministries. For example: Widow's coin, widow's might, pearl of great price, good seeds that fell upon good soil and so on to explain the value and appreciation for their opinion.

(4) The fourth is to "Plan:" Planning helps keep the church focused on activities and accountability. It assists Ministry leaders in prioritizing their time to focus their energies on achievable and productive matters.

(5) The fifth is to "identify the vita view:" Identify those in the Ministry that can get things done. Going beyond the traditional leadership structure i.e., those who have been "officially elected" in the ministry, working alongside others on essential and achievable goals.

(6) The sixth is "do not overrule consensus:” Pastors or Ministry leaders are called to the task of peace and reconciliation. Transformational leadership in ministries is rebirth and renewal. Ministry leaders should 
welcome, endure, and expect conflict. Valuing the general opinion and welcoming ideas of those in ministry immediately and not waiting until later.

(7) The seventh is to "count the yes vote:" It is better to get approval and support from lay persons as Willimon stated "rarely will a new ministry get support from the first particularly if the new ministry requires risk."

(8) The eighth is to "create a new working group for a new job:" Encourage innovation by having those feels called to a new task in undertaking new initiatives and directions. This will ensure productivity.

(9) The ninth is to "change by addition, not subtraction:" Always encourage new initiatives and have congregants be a part of the project. This way, they feel that their opinions matter and will be apt to participate and initiate new things in the future.

(10) The tenth is to "be persistent:" Any kind of change provokes resistance especially where the service and devotion to God is of matter. One of the essential virtues of Christian ministry is to be constant.

\section{Conclusion}

Leadership in the 21st century ministry requires organizational leaders to adapt to change and to lead different types of people. ${ }^{18}$ It requires pastors and ministry leaders to be accountable. The author describes the many different roles of a pastor and the peculiarity of Christian leadership. Mentioning the Acts of Apostles as the basis of Christian Leadership, Willimon discussed that the book of Acts narrates the triumphs, tribulations. Understanding the role of the pastor or ministry leader as someone in position of power does not mean abuse of authority. The ability of an ordained pastor to possess power goes beyond spiritual anointed power. Transformational leadership and the role of a church leader requires organization change, changing people and motivating them into fruitful Christians and effective future leaders in their respective communities. A qualified leader displays all four dimensions of transformational leadership theory, goes beyond the call of duty, as a servant leader, sacrifices to serve community and strives to achieve goals set by the group. In return, such a leader is respected better as a pastor or ministry leader.

\section{Notes}

1. Willimon, 2002.

2. Alapo, 2018, 1.

3. Dubois, 2006, as cited in Alapo, 2011, 48.

4. Evans, 1996, as cited in Alapo, 2011, 48.

5. Avolio, B. J., Bhatia, P., Koh, W., and Zhu, W., 2004; Goleman, 1998.

6. Willimon, 2002, 277.

7. Transformational Leadership section as cited on pages 20-21 of Alapo, 2011.

8. Alapo, 2018, 89-90.

9. Burns, 1978.

10. Givens, 2008.

11. Bass, 1990.

12. Bass, 1990.

13. Bass, 1990; 1985.

14. Bass, 1999.

15. Wofford, 2001; Banerji and Krishnan, 2000.

16. The section of this paper is based on a collaborative effort of Dr. Remi Alapo and David Rock, a peace loving world citizen, who advocates for peace and justice in many underserved communities.

17. Willimon, 2002, 27-28. 
18. Alapo, R. 2011.

\section{Works Cited}

Alapo, R. "Organizational Power Politics and Leadership Experiences on the View and Use of Power in Organizations.” Management Studies, Jan.-Feb. 2018, Vol. 6, No. 1, 30-36.

---. “The Role of Culture on the Leadership Styles of Women in Leadership Positions: A Phenomenological Study.” Unpublished manuscript. Arizona: School of Advanced Studies, University of Phoenix, 2011. 188.

Avolio, B. J., Bhatia, P., Koh, W., and Zhu, W. “Transformational Leadership and Organizational Commitment: Mediating Role of Psychological Empowerment and Moderating Role of Structural Distance.” Journal of Organizational Behavior 25 (2004): 951-68. Doi:10.1002/job.283.

Banerji, P. and Krishnan, V. R. "Ethical Preferences of Transformational Leaders: An Empirical Investigation.” Leadership \& Organization Development Journal 21.8 (2000): 405.

Bass, B. M. "Two Decades of Research and Development in Transformational Leadership.” European Journal of Work and Organizational Psychology 8.1 (1999): 9-32.

---. Leadership and Performance beyond Expectations. New York: Free Press, 1985.

Bass, B. M. and Avolio, B. J. Improving Organizational Effectiveness through Transformational Leadership. Thousand Oaks, CA: Sage, 1994.

Burns, J. M. Leadership. New York: Harper \& Row, 1978.

Givens, R. J. “Transformational Leadership: The Impact on Organizational and Personal Outcomes.” Emerging Leadership Journeys 1.1 (2008): 4-24.

Goleman, D. “What Makes a Leader?” Harvard Business Review 76.6 (Nov.-Dec., 1998): 93-102.

McCall, M. W., Jnr. “Leadership and Performance beyond Expectations.” New York: The Free Press, 1985. 191.

Willimon, H. W. Pastor: The Theology and Practice of Ordained Ministry. Nashville: Abingdon Press, 2002.

Wofford, J. C., Whittington, J. L., Goodwin, V. L., and Vicki L. "Follower Motive Patterns as Situational Moderators for Transformational Leadership Effectiveness.” Journal of Managerial Issues 13.2 (Sum. 2001): 1045-3695. 